\title{
Correction to: Reactive oxygen species- dependent mitochondrial dynamics and autophagy confer protective effects in retinal pigment epithelial cells against sodium iodate-induced cell death
}

\author{
Chi-Ming Chan 1,2,3, Duen-Yi Huang ${ }^{1,4}$, Ponarulselvam Sekar ${ }^{1,4}$, Shu-Hao Hsu² and Wan-Wan Lin ${ }^{1,4^{*}}$
}

\section{Correction to: J Biomed Sci}

https://doi.org/10.1186/s12929-019-0531-z

After the publication of this article [1], the authors would like to clarify that some immunoblotting data in Figs. 2f, 3a and 4b were obtained from the same samples but individual SDS-PAGE gels. Therefore, the authors would like to add a separate line between these data, i.e. Drp-1 and Drp-1-p in Fig. 2f; LC3I/II and p62 in Fig. 3a and p38-p and p38 in Fig. 4b. The correction figures for the entire Figs. 2, 3 and 4 have been included below.

\section{Author details \\ 'Department of Pharmacology, College of Medicine, National Taiwan University, Taipei, Taiwan. ${ }^{2}$ Department of Ophthalmology, Cardinal Tien Hospital, New Taipei City, Taiwan. ${ }^{3}$ School of Medicine, Fu Jen Catholic University, New Taipei City, Taiwan. ${ }^{4}$ Graduate Institute of Medical Sciences, Taipei Medical University, Taipei, Taiwan.}

Published online: 04 September 2019

\section{Reference}

1. Chan C-M, Huang D-Y, Sekar P, Hsu S-H, Lin W-W. Reactive oxygen speciesdependent mitochondrial dynamics and autophagy confer protective effects in retinal pigment epithelial cells against sodium iodate-induced cell death. J Biomed Sci. 2019;26:40.

\footnotetext{
* Correspondence: wwllaura1119@ntu.edu.tw

'Department of Pharmacology, College of Medicine, National Taiwan University, Taipei, Taiwan

${ }^{4}$ Graduate Institute of Medical Sciences, Taipei Medical University, Taipei,

Taiwan

Full list of author information is available at the end of the article
}

C The Author(s). 2019 Open Access This article is distributed under the terms of the Creative Commons Attribution 4.0 International License (http://creativecommons.org/licenses/by/4.0/), which permits unrestricted use, distribution, and reproduction in any medium, provided you give appropriate credit to the original author(s) and the source, provide a link to the Creative Commons license, and indicate if changes were made. The Creative Commons Public Domain Dedication waiver (http://creativecommons.org/publicdomain/zero/1.0/) applies to the data made available in this article, unless otherwise stated. 


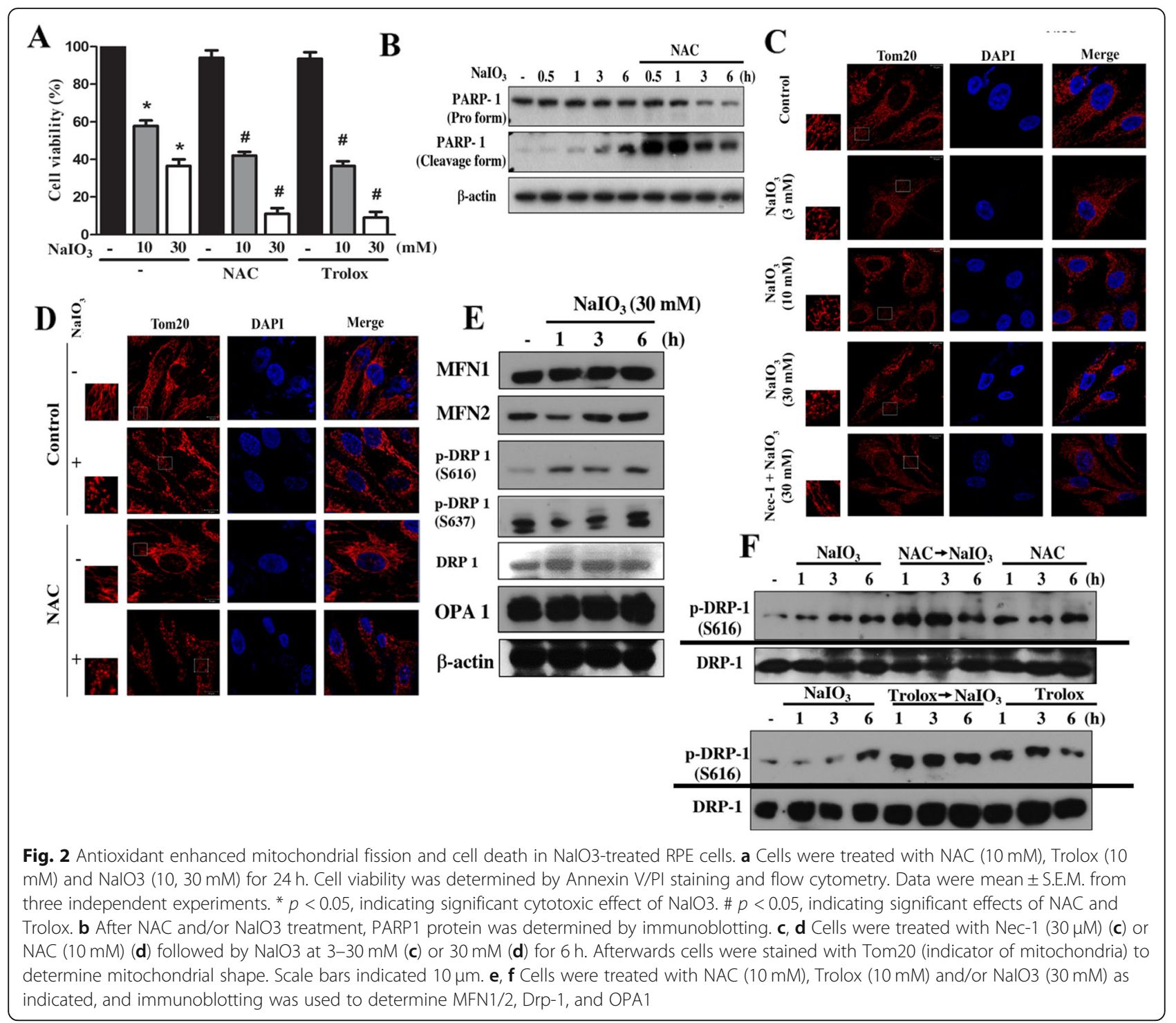




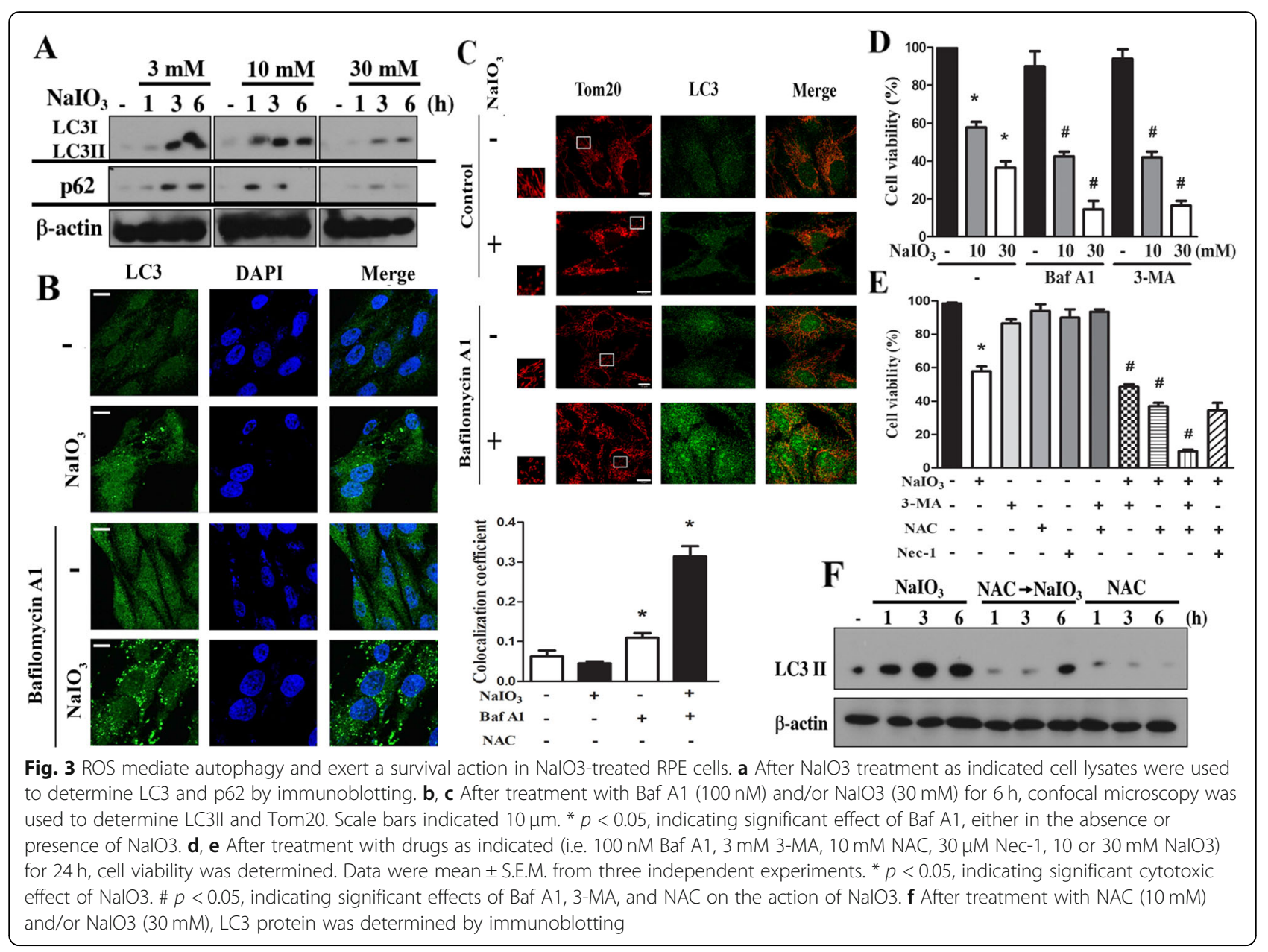




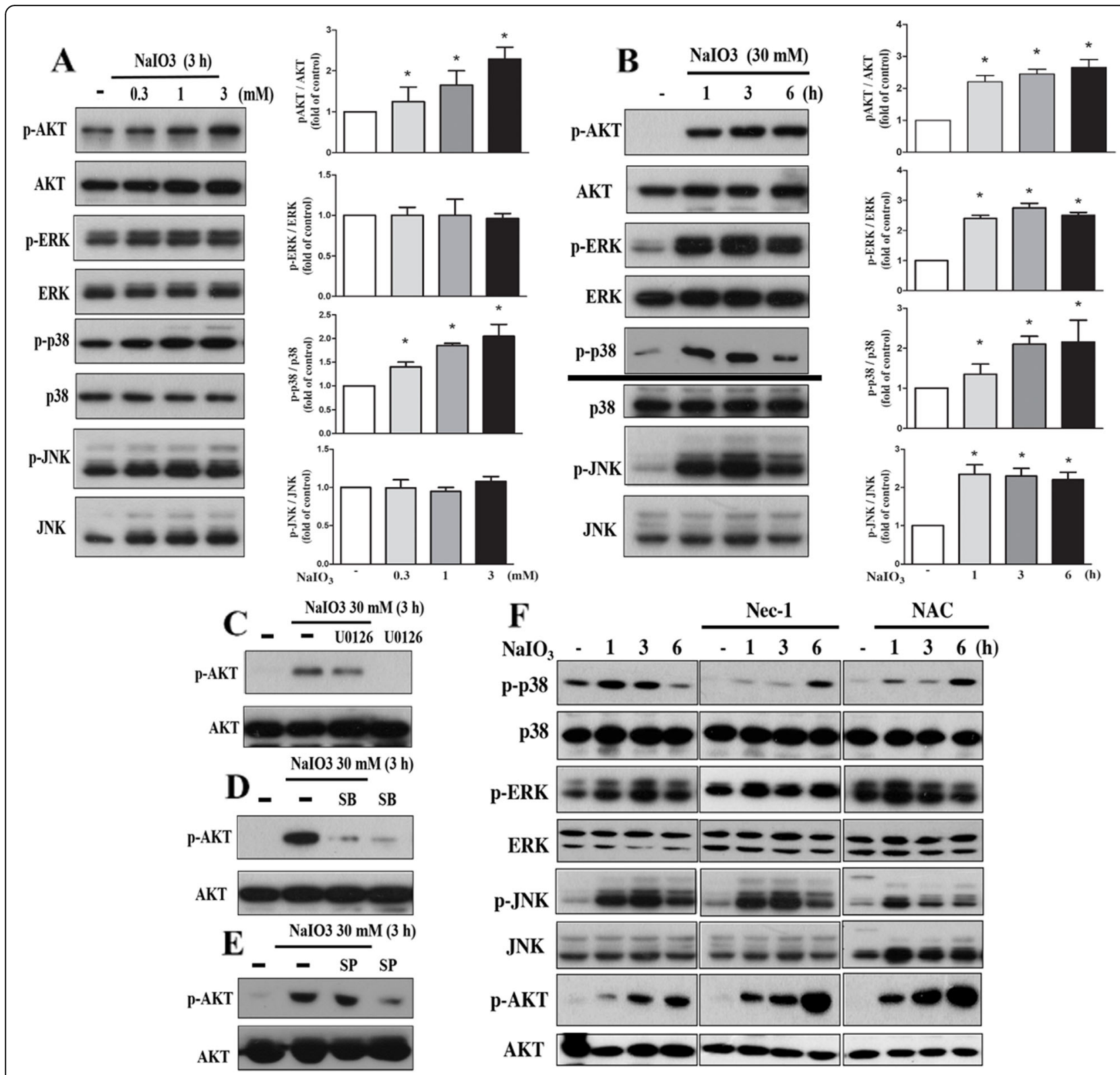

Fig. $4 \mathrm{NalO3}$ induces Akt, ERK, JNK and p38 MAPK activation. a, b As indicated, cells were treated with NalO3 at concentrations indicated for different intervals. Immunoblotting was conducted by specific antibodies to determine the total and phosphorylated forms of Akt, ERK, p38 MAPK and JNK. Quantification of protein phosphorylation was determined by normalization with respective total protein levels. ${ }^{*} p<0.05$, indicating significant activation effects of $\mathrm{NalO3}$ on signaling pathways. c-f Cells were pretreated with U0126 (ERK inhibitor, $10 \mu \mathrm{M})(\mathbf{c})$, SB203580 (p38 MAPK inhibitor, $10 \mu \mathrm{M})(\mathbf{d})$, SP600125 (JNK inhibitor, $10 \mu \mathrm{M})(\mathbf{e})$, Nec-1 (RIP1 inhibitor, $30 \mu \mathrm{M})(\mathbf{f})$ or NAC (10 mM) (f) for 15 min. Then cells were treated with $\mathrm{NalO} 3(30 \mathrm{mM})$ for $3 \mathrm{~h}$ (c-e) or different time intervals (f). Cell lysates were collected for immunoblotting 